\title{
ANALISIS LOKASI PADA PERENCANAAN TERMINAL TOPOYO MAMUJU TENGAH
}

\author{
Amiruddin Akbar Fisu ${ }^{1)}$ \\ ${ }^{1)}$ Dosen Fakultas Teknik Universitas Andi Djemma Palopo \\ 1) amiruddinakbarfisu07@gmail.com
}

\begin{abstract}
Abstrak
Pada perencanaan terminal yang baik adalah yang perencanaan lokasinya secara sistem jaringan mampu berperan dalam melancarkan pergerakan sistem transportasi secara keseluruhan, dengan demikian perencanaan dan pengembangannya perlu ditata dalam satu kesatuan sistem yang terpadu. Oleh karena itu penelitian ini bertujuan untuk menganalisis lokasi perencanaan Terminal Topoyo, Mamuju Tengah, baik secara makro maupun mikro. Letak terminal sangatlah berperan, terutama dalam kaitannya dengan peran yang disandang oleh terminal bersangkutan dalam sistem jaringan rute ataupun keberadaan terminal tersebut dalam system prasarana jaringan jalan. Jenis studi ini adalah deskriptif evaluatif dengan membandingkan kriteria lokasi terminal yang ideal dengan kondisi alternatif-alternatif lokasi yang ada. Analisis terbagi menjadi dua, yaitu analisis lokasi terminal decara makro dan secara mikro. Analisis lokasi secara makro dilakukan dengan metode skoring berdasarkan tujuh kriteria lokasi terminal yang telah ditetapkan. Sedangkan untuk Analisis lokasi secara mikro, juga menggunakan teknik analisis skoring dan matriks kinerja (performance matrix) yang merupakan representasi dari tingkat pemenuhan kriteria dari suatu alternatif yang merupakan hasil perkalian dari skor alternative terhadap variabel kriteria dengan besarnya bobot setiap kriteria. Hasil analisis makro, dengan menggunakan metode skoring dan penilaian kualitatif, maka terpilih lokasi alternatif pertama. Pada lokasi tersebut dianalisis mikro dengan juga menggunakan teknik analisis skoring dan matriks kinerja (performance matrix) maka diperoleh hasil pada Lokasi 1 (nilai 87.397) ditetapkan sebagai lokasi terbaik dalam pembangunan terminal di Kabupaten Mamuju Tengah dibandingkan dengan lokasi alternatif 2 yang hanya memiliki nilai 84.613 .
\end{abstract}

Kata Kunci: Analisis Lokasi Terminal, Terminal Topoyo.

\section{PENDAHULUAN}

Kabupaten Mamuju Tengah sebagai daerah pemekaran dipandang sebagai sebuah terobosan untuk mempercepat pembangunan melalui peningkatan kualitas dan kemudahan memperoleh pelayanan bagi masyarakat. Terdapat berbagai alasan kenapa pemekaran wilayah dapat dianggap sebagai salah satu pendekatan dalam kaitannya dengan penyelenggaraan pemerintah daerah dan peningkatan publik, salah satunya adalah untuk menyediakan pelayanan publik yang lebih baik dalam wilayah kewenangan yang terbatas / terukur, termasuk pelayanan transportasi. Menurut Humang (2016), pembangunan sarana transportasi memiliki hubungan timbal balik dengan perekonomian suatu daerah untuk menunjang perkembangan kawasan perkotaan dan pedesaan. Salah satu prasarana transportasi yang sangat vital adalah Terminal Angkutan Penumpang sesuai dengan Keputusan Menteri Perhubungan Nomor 31 Tahun 1995 tentang Terminal Transportasi Jalan. Selama ini pembangunan terminal banyak yang kurang memiliki landasan perencanaan secara matang sehingga kurang fungsional.

Pada perencanaan terminal yang baik adalah perencanaan terminal yang lokasinya secara sistem jaringan mampu berperan dalam melancarkan pergerakan sistem transportasi secara keseluruhan, dengan demikian perencanaan dan pengembangannya perlu ditata dalam satu kesatuan sistem yang terpadu. Menurut Fisu (2016), salah satu ciri kota atau zona yang dapat mempengaruhi pemilihan moda transportasi adalah kepadatan penduduk dan jarak dari pusat kota. Hal ini didukung oleh Natsir (2016) yang menyatakan ruang yang harus disediakan oleh kota untuk 
dijadiakn prasarana transportasi dapat mempengaruhi pemilihan moda transportasi. Oleh karena itu penelitian ini bertujuan untuk menganalisis lokasi perencanaan Terminal Topoyo, mamuju tengah, baik secara makro maupun mikro. Letak terminal sangatlah berperan, terutama dalam kaitannya dengan peran yang disandang oleh terminal bersangkutan dalam sistem jaringan rute ataupun keberadaan terminal tersebut dalam system prasarana jaringan jalan.

\section{Persyaratan Lokasi Terminal}

Dalam penentuan lokasi terminal untuk setiap tipe tersebut, pemerintah Republik Indonesi telah menetapkan persyaratan lokasi untuk tiga tipe terminal di atas melalui Keputusan Direktur Jenderal Perhubungan Darat No.31 Tahun 1995 Tentang Terminal Transportasi Jalan yaitu :

a) Persyaratan Lokasi Terminal Tipe A, yaitu: (1) Terletak di ibukota propinsi, kota, atau kabupaten dalam jaringan trayek antar kota antar propinsi dan/atau angkutan lintas batas negara; (2) Terletak pada jaringan jalan arteri dengan kelas jalan sekurang-kurangnya kelas III-A; (3) Jarak antara dua terminal penumpang tipe A sekurang-kurangnya $20 \mathrm{Km}$ di Pulau Jawa, $30 \mathrm{Km}$ di Pulau Sumatera, dan berjarak $50 \mathrm{Km}$ di pulau-pulau lainnya; (4) Luas lahan yang tersedia sekurang-kurangnya 5 Ha untuk terminal di Pulau Jawa dan Pulau Sumatera, dan sekurang-kurangnya 3 Ha untuk terminal di pulau-pulau lainnya; dan (5) Mempunyai jalan akses masuk dan jalan keluar ke dan dari terminal, sekurang-kurangnya berjarak $100 \mathrm{~m}$ untuk terminal di Pulau Jawa dan $50 \mathrm{~m}$ untuk terminal di pulau-pulau lainnya. Penentuan lokasi dan letak terminal tipe A dilaksanakan oleh Direktur Jenderal Perhubungan Darat setelah mendengar masukan dan pendapat dari Gubernur Propinsi setempat.

b) Persyaratan Lokasi Terminal Tipe B, yaitu: (1) Terletak di ibukota kotamadya, atau kabupaten dalam jaringan trayek antar kota dalam propinsi; (2) Terletak pada jaringan jalan arteri atau kolektor dengan kelas jalan sekurangkurangnya kelas IIIB; (3) Jarak antara dua terminal penumpang tipe B atau dengan terminal tipe A sekurang-kurangnya $15 \mathrm{Km}$ di Pulau Jawa, dan berjarak $30 \mathrm{Km}$ di pulau-pulau lainnya; (4) Luas lahan yang tersedia sekurang-kurangnya 3 Ha untuk terminal di Pulau Jawa dan Pulau Sumatera, dan sekurang-kurangnya 2 Ha untuk terminal di pulau-pulau lainnya; dan (5) Mempunyai jalan akses masuk dan jalan keluar ke dan dari terminal, sekurang-kurangnya berjarak $50 \mathrm{~m}$ untuk terminal di Pulau Jawa dan $30 \mathrm{~m}$ untuk terminal di pulau-pulau lainnya. Penentuan lokasi dan letak terminal tipe B dilaksanakan oleh Gubernur Propinsi setempat.

\section{Faktor-Faktor yang Mempengaruhi Lokasi Terminal}

Penentuan lokasi terminal penumpang harus memperhatikan faktor-faktor:

a) Aksesibilitas, yaitu tingkat pencapaian kemudahan yang dapat dinyatakan dengan jarak, waktu atau biaya angkutan.

b) Struktur Wilayah, dimaksudkan untuk mencapai efisiensi maupun efektifitas pelayanan terminal terhadap elemen-elemen perkotaan yang mempunyai fungsi primer dan sekunder.

c) Lalu lintas, terminal merupakan pembangkit lalu lintas. Oleh karena itu penentuan lokasi terminal harus tidak lebih menimbulkan dampak lalu lintas tetapi sebaliknya harus dapat mengurangi dampak lalu lintas.

d) Biaya, penentuan lokasi terminal perlu memperhatikan biaya yang dikeluarkan oleh pemakai jasa. Oleh karenanya faktor biaya harus dipertimbangkan agar penggunaan angkutan umum dapat diselenggarakan secara cepat, aman, dan murah. 


\section{METODE PENELITIAN}

Jenis studi ini adalah deskriptif evaluatif dengan membandingkan kriteria lokasi terminal yang ideal dengan kondisi alternatif-alternatif lokasi yang ada. Analisis terbagi menjadi dua, yaitu analisis lokasi terminal decara makro dan secara mikro. Analisis lokasi secara makro dilakukan dengan metode skoring berdasarkan tujuh kriteria lokasi terminal yang telah ditetapkan. Sedangkan untuk Analisis lokasi secara mikro, juga menggunakan teknik analisis skoring dan Matriks kinerja (performance matrix) yang merupakan representasi dari tingkat pemenuhan kriteria dari suatu alternatif yang merupakan hasil perkalian dari skor alternative terhadap variabel kriteria dengan besarnya bobot setiap kriteria. Contoh pembentukan matriks kinerja disampaikan pada Tabel 4.8. Penyimpulan prioritas untuk setiap alternatif ditentukan oleh besarnya nilai kinerja alternatif $(\mathrm{Pi})$, di mana alternatif yang menunjukkan nilai $\mathrm{Pi}$ yang lebih besar akan lebih diprioritaskan.

Tabel 1. Pembentukan Matrik Kinerja

\begin{tabular}{|l|l|l|l|l|l|}
\hline & Kriteria 1 & Kriteria 2 & Kriteria 3 & Kriteria 4 & Kinerja \\
\hline Alternatif 1 & $\mathrm{S}_{11} * \mathrm{~W}_{1}$ & $\mathrm{~S}_{12} * \mathrm{~W}_{2}$ & $\mathrm{~S}_{13} * \mathrm{~W}_{3}$ & $\mathrm{~S}_{14} * \mathrm{~W}_{4}$ & $\mathrm{P}_{1}$ \\
\hline Alternatif 2 & $\mathrm{S}_{21} * \mathrm{~W}_{1}$ & $\mathrm{~S}_{22} * \mathrm{~W}_{2}$ & $\mathrm{~S}_{23} * \mathrm{~W}_{3}$ & $\mathrm{~S}_{24} * \mathrm{~W}_{4}$ & $\mathrm{P}_{2}$ \\
\hline & & & & & \\
\hline & & & & & \\
\hline Alternatif $\mathrm{i}$ & $\mathrm{Si}_{1} * \mathrm{~W}_{1}$ & $\mathrm{Si}_{2} * \mathrm{~W}_{2}$ & $\mathrm{~S}_{3} * \mathrm{~W}_{3}$ & $\mathrm{Si}_{1} * \mathrm{~W}_{4}$ & $\mathrm{P}_{\mathrm{i}}$ \\
\hline
\end{tabular}

Keterangan:

$\mathrm{Sij} \quad=$ Skor alternatif $\mathrm{i}$ thd kriteria $\mathrm{j}$

$\mathrm{Wj} \quad=$ Bobot kriteria $\mathrm{j}$

Sij* $\mathrm{Wj}=$ Skor terbobotkan (weighted score)

$\mathrm{Pi} \quad=$ Kinerja alternatif $\mathrm{i}=\Sigma \mathrm{Sij}^{*} \mathrm{Wij}$

\section{HASIL DAN PEMBAHASAN}

Analisis Pemilihan Lokasi Makro

Terminal penumpang yang sudah ada di kabupaten Mamuju Tengah adalah Terminal di Kawasan KTM Tobadak (type B) kondisinya sudah dibangun, hanya belum difungsikan sebagai terminal yang melayani angkutan antar kabupaten dan antar provinsi. Selain itu terdapat sebuah terminal tidak resmi di Kecamatan Karossa yang berfungsi sebagai tempat pemberhentian sementara angkutan.

Kedua lokasi terminal ini tidak begitu dipertimbangkan pada analisis lokasi ini dikarenakan lokasinya yang berada di kawasan padat sehingga cukup sulit untuk menyediakan wilayah pengembangan terminal kedepan. Namun untuk KTM Topoyo dapat dipertimbangkan sebagai terminal angkutan kota/ pedesaan mengingat letaknya yang berada di pusat kegiatan. Sedangkan terminal di Kecamatan Karossa juga dapat dijadikan pangkalan angkutan kota dan pedesaan serta lokasi check point AKAP dan AKADP sebelum keluar atau setelah masuk dari dan ke wilayah Mamuju tengah.

Sebelum diperoleh lokasi tapak terminal terpilih terlebih dahulu dilakukan peninjauan beberapa alternatif lokasi secara makro yang terkait dengan faktor-faktor dan persyaratan dalam pemilihan lokasi terminal. Agar penilaian dapat dilakukan terlebih dahulu disusun beberapa kriteria pemilihan lokasi yang akan menjadi dasar terhadap pemilihan alternatif lokasi terminal secara makro, kemudian dilakukan pemilihan alternatif lokasi terminal yang nantinya akan ditetapkan sebagai lokasi makro terminal terpilih dengan metode Analisis Multi Kriteria.

\section{a. Pemilihan Alternatif Lokasi Makro Terminal}

Berdasarkan kesesuaian pola tata ruang serta rencana yang tertuang dalam dalam 
RDRT, maka lokasi yang terpilih sebagai alternatif penempatan terminal adalah seperti yang terlihat pada peta di bawah ini, dimana lokasi alternatif tersebut adalah:

1) Alternatif 1 adalah terletak di Kecamatan Budong-budong

2) Alternatif 2 adalah terletak di Kecamatan Karossa

Pemilihan lokasi ini dilakukan berdasarkan pertimbangan-pertimbangan terhadap kriteria pemilihan lokasi yang telah ditetapkan sebelumnya.

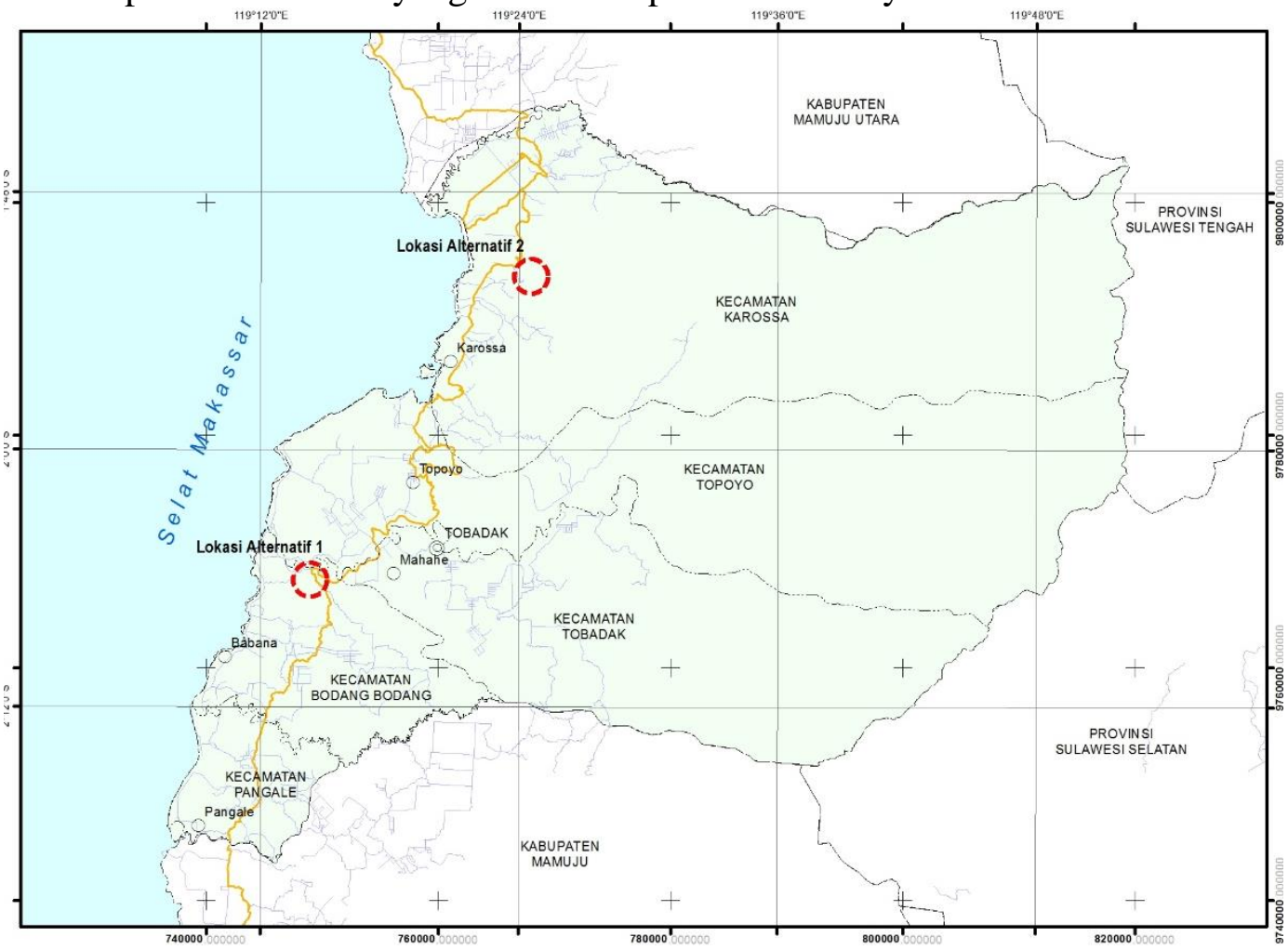

Gambar 1. Alternatif Rencana Lokasi Terminal

\section{b. Analisis Pemilihan Lokasi Makro Terminal dengan Metode Skoring}

Menurut Humang (2016) Kegiatan transportasi harus dilakukan secara menyeluruh dengan keterpaduan fisik antar moda berupa titik simpul pertemuan antar moda. Hal ini menuntut lokasi terminal yang strategis. Untuk mendapatkan lokasi makro terminal terlebih dahulu dilakukan skoring terhadap kriteria-kriteria yang telah ditentukan terhadap alternatif lokasi makro terminal yang telah di dapat, dimana nilai range dari setiap skor mempunyai arti kualitatif seperti pada Tabel 4.2 dibawah ini.

Tabel 2. Nilai Skor Setiap Kriteria Penilaian Lokasi Makro

\begin{tabular}{|c|c|c|c|c|c|c|}
\hline \multirow{2}{*}{ No } & & \multirow{2}{*}{ Kriteria Penilaian } & \multicolumn{4}{|c|}{ Ket. Nilai Skor (10 s.d. 0) } \\
\hline & & & $\geq 9$ & $8-6$ & $5-4$ & $\leq 3$ \\
\hline \multirow{5}{*}{1} & & a Ruang & & & & \\
\hline & $\mathrm{a}$ & Kesesuaian dengan RTRW & $\begin{array}{c}\text { Sangat } \\
\text { mendukung }\end{array}$ & Mendukung & Cukup & Kurang \\
\hline & $\mathrm{b}$ & Daya dukung lahan sekitar & $\begin{array}{c}\text { Sangat } \\
\text { mendukung }\end{array}$ & Mendukung & Cukup & Kurang \\
\hline & $\mathrm{c}$ & $\begin{array}{l}\text { Potensi pengembangan wilayah dan } \\
\text { pertumbuhan ekonomi }\end{array}$ & $\begin{array}{c}\text { Sangat } \\
\text { mendukung }\end{array}$ & Mendukung & Cukup & Kurang \\
\hline & d & $\begin{array}{ll}\text { Mendekati wilayah } & \text { rencana } \\
\text { kawasan potensial } & \end{array}$ & Sangat Dekat & Dekat & Jauh & $\begin{array}{c}\text { Sangat } \\
\text { Jauh }\end{array}$ \\
\hline
\end{tabular}

2 Transportasi 


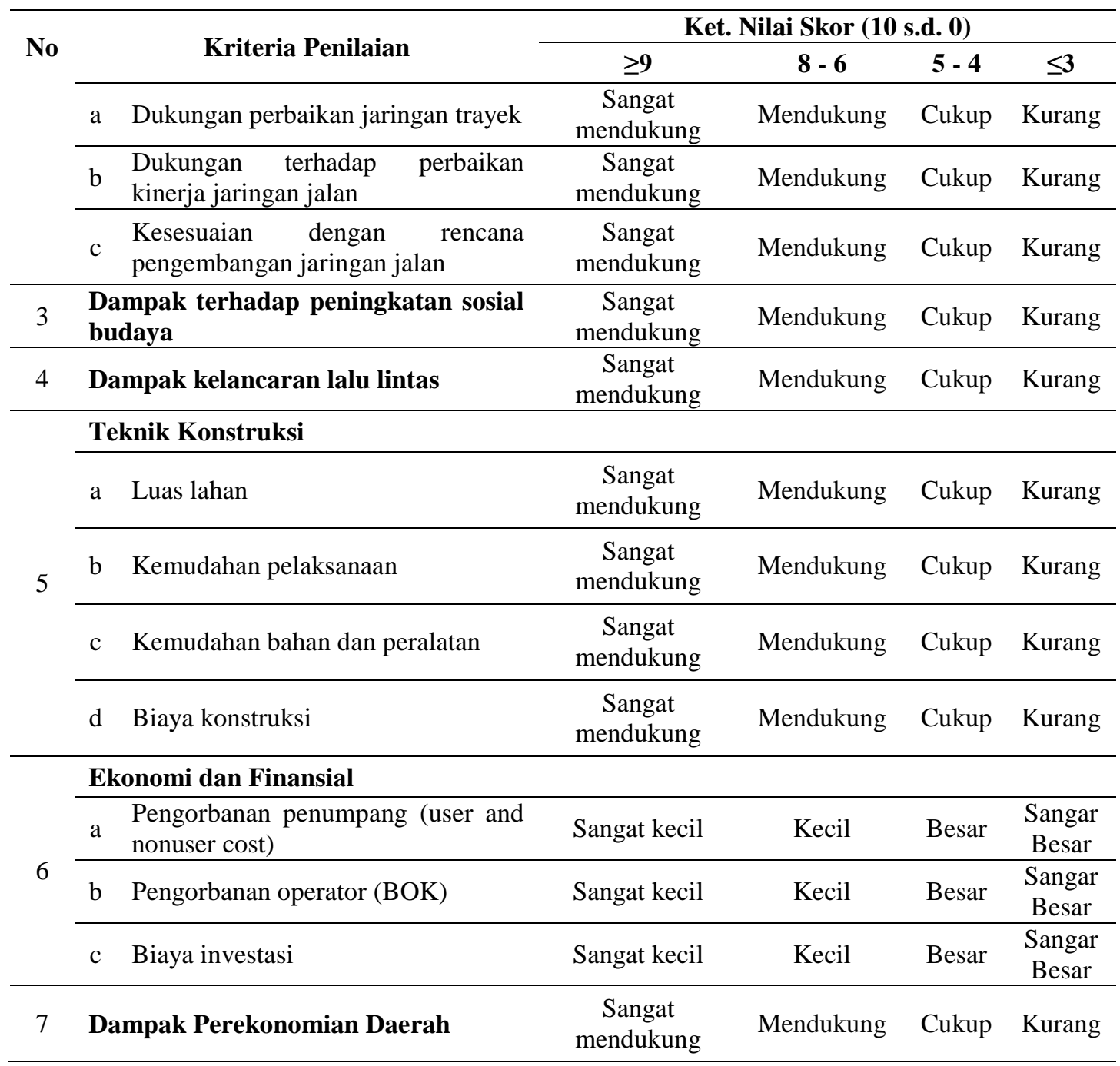

Salah satu kriteria penentuan lokasi adalah kesesuaian dengan RTRW. Menurut Rita (2014) Faktor penggunaan lahan menjadi pertimbangan dalam analisa lokasi terminal, karena lokasi terminal yang terpilih harus sesuai dengan RTRW. Setelah skoring terhadap setiap kriteria dilakukan, maka selanjutnya dilakukan penilaiaan kualitatif dari sertiap kriteria yang diberikan terhadap kedua alternative lokasi makro terminal yang telah dipilih tersebut seperti pada Tabel di bawah terpilih lokasi alternatif satu.

Tabel 3. Skoring Setiap Kriteria Terhadap Lokasi Alternatif Makro Terminal

\begin{tabular}{|c|c|c|c|}
\hline \multirow{2}{*}{ No } & \multirow{2}{*}{ Kriteria Penilaian } & \multicolumn{2}{|c|}{ Skoring lokasi alternatif } \\
\hline & & $\mathbf{1}$ & 2 \\
\hline \multirow{5}{*}{1} & \multicolumn{3}{|l|}{ Tata Ruang } \\
\hline & a Kesesuaian dengan RTRW & 9 & 9 \\
\hline & b Daya dukung lahan sekitar & 9 & 8 \\
\hline & $\begin{array}{l}\text { Potensi pengembangan wilayah dan pertumbuhan } \\
\text { ekonomi }\end{array}$ & 8 & 8 \\
\hline & d Mendekati wilayah rencana kawasan potensial & 8 & 8 \\
\hline \multirow{2}{*}{2} & \multicolumn{3}{|l|}{ Transportasi } \\
\hline & a Dukungan perbaikan jaringan trayek & 9 & 8 \\
\hline
\end{tabular}




\begin{tabular}{|c|c|c|c|}
\hline \multirow{4}{*}{ No } & \multirow{2}{*}{ Kriteria Penilaian } & \multicolumn{2}{|c|}{ Skoring lokasi alternatif } \\
\hline & & 1 & 2 \\
\hline & b Dukungan terhadap perbaikan kinerja jaringan jalan & 9 & 9 \\
\hline & $\begin{array}{l}\text { Kesesuaian dengan rencana pengembangan jaringan } \\
\text { jalan }\end{array}$ & 9 & 8 \\
\hline 3 & Dampak terhadap peningkatan sosial budaya & 8 & 8 \\
\hline 4 & Dampak kelancaran lalu lintas & 9 & 9 \\
\hline \multirow{5}{*}{5} & Teknik Konstruksi & & \\
\hline & a Luas lahan & 9 & 9 \\
\hline & b Kemudahan pelaksanaan & 9 & 8 \\
\hline & c Kemudahan bahan dan peralatan & 9 & 8 \\
\hline & d Biaya konstruksi & 9 & 8 \\
\hline \multirow{4}{*}{6} & Ekonomi dan Finansial & & \\
\hline & a $\quad$ Pengorbanan penumpang (user and nonuser cost) & 7 & 7 \\
\hline & b Pengorbanan operator (BOK) & 7 & 7 \\
\hline & c Biaya investasi & 9 & 9 \\
\hline \multirow[t]{2}{*}{7} & Dampak Perekonomian Daerah & 8 & 8 \\
\hline & Jumlah & 145 & 139 \\
\hline
\end{tabular}

\section{Analisis Perencanaan Lokasi Mikro}

Setelah terpilih lokasi makro terminal melalui proses SWOT dan skoring, maka tahap selanjutnya akan dipilih lokasi tapak terminal (lokasi mikro) yang berada dalam lokasi makro terminal terpilih. Luas lokasi yang akan menjadi tapak terminal adalah seluas $\pm 2 \mathrm{Ha}$.

Proses pemilihan lokasi mikro tapak terminal sedikit berbeda dengan proses pemilihan lokasi makro terminal. Pada pemilihan lokasi mikro terminal ini akan menggunakan metoda pendekatan Analisis Multi Kriteria.

\section{a) Lokasi Alternatif Tapak Terminal}

Berdasarkan hasil survey lapangan pada lokasi makro terminal terpilih maka ditentukan ada 2 lokasi alternatif rencana tapak terminal, yang mana lokasi tapak terminal tersebut dapat dilihat pada berikut. Pada Gambar 2 sampai dengan Gambar 3 ditampilkan situasi area lokasi tapak untuk 2 alternatif lokasi tapak Terminal tipe B Mamuju Tengah.

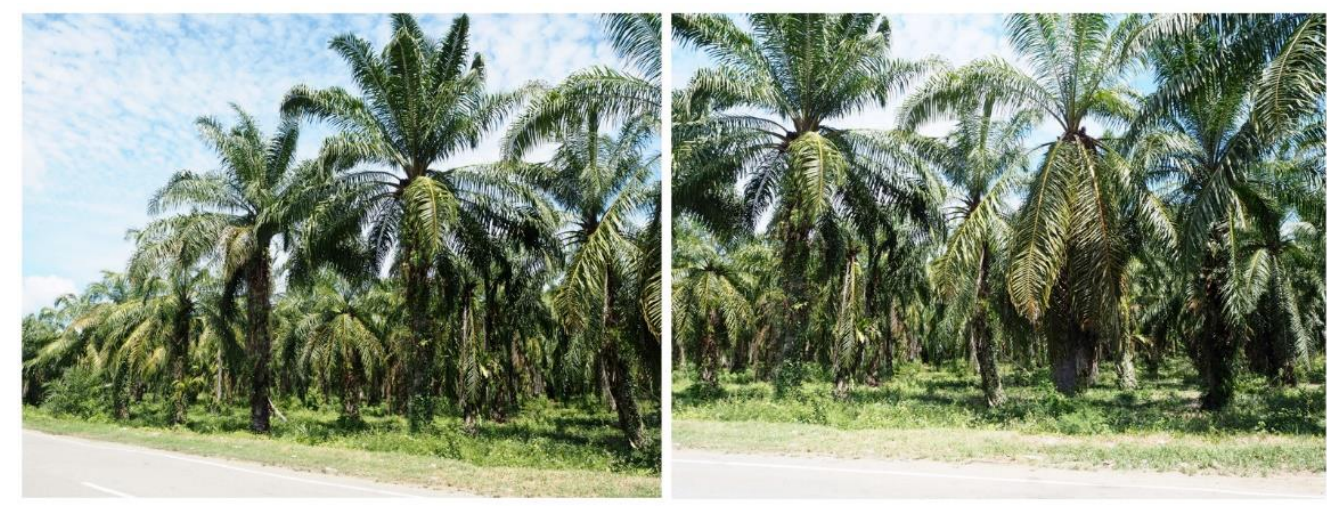

Gambar 2. Gambar Situasi Lokasi Mikro Alternatif 1 


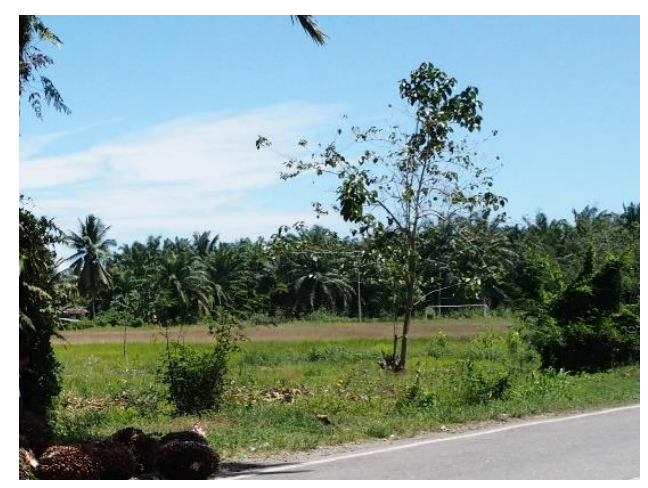

Gambar 3. Gambar Situasi Lokasi Mikro Alternatif 2

\section{b) Analisis Multi Kriteria Pemilihan Lokasi Mikro}

Untuk mendapatkan lokasi mikro tapak terminal terpilih terlebih dahulu dilakukan skoring terhadap krteria-kriteria yang telah ditentukan terhadap alternatif lokasi mikro tapak terminal yang telah di dapat, dimana nilai range dari setiap skor mempunyai arti kualitatif seperti pada Tabel dibawah ini.

Tabel 4. Nilai Skor Setiap Kriteria Penilaian Lokasi Mikro

\begin{tabular}{|c|c|c|c|c|c|}
\hline \multirow{2}{*}{ No } & \multirow{2}{*}{ Kriteria Penilaian } & \multicolumn{4}{|c|}{ Ket. Nilai Skor (100 s.d. 0) } \\
\hline & & $\geq 90$ & $80-60$ & $50-40$ & $\leq \mathbf{3 0}$ \\
\hline 1 & $\begin{array}{l}\text { Kondisi luas daratan dan } \\
\text { kontur }\end{array}$ & $\begin{array}{l}\text { Sangat } \\
\text { Mendukung }\end{array}$ & Mendukung & Cukup & Kurang \\
\hline 2 & Kestabian tanah dasar & $\begin{array}{c}\text { Sangat } \\
\text { Mendukung }\end{array}$ & Mendukung & Cukup & Kurang \\
\hline 3 & $\begin{array}{ll}\begin{array}{l}\text { Kemudahan } \\
\text { pembangunan }\end{array} & \text { dalam } \\
\end{array}$ & Sangat Ideal & Ideal & Kurang Ideal & Tidak Ideal \\
\hline 4 & Kedekatan dengan akses jalan & Sangat Dekat & Dekat & $\begin{array}{c}\text { Kurang } \\
\text { Dekat }\end{array}$ & Jauh \\
\hline 5 & Kesesuaian dengan RTRW & $\begin{array}{l}\text { Sangat } \\
\text { Mendukung }\end{array}$ & Mendukung & Cukup & Kurang \\
\hline 6 & $\begin{array}{l}\text { Kedekatan dengan jaringan } \\
\text { jalan eksisting }\end{array}$ & $\begin{array}{c}\text { Sangat } \\
\text { Mendukung }\end{array}$ & Mendukung & Cukup & Kurang \\
\hline 7 & Pola tata guna lahan di lokasi & $\begin{array}{l}\text { Sangat } \\
\text { Mendukung }\end{array}$ & Mendukung & Cukup & Kurang \\
\hline 8 & Kondisi hidrologi & $\begin{array}{c}\text { Sangat } \\
\text { Mendukung }\end{array}$ & Mendukung & Cukup & Kurang \\
\hline
\end{tabular}

Setelah skoring terhadap setiap kriteria dilakukan, maka selanjutnya dilakukan penilaiaan kualitatif dari sertiap kriteria yang diberikan terhadap keempat alternative lokasi tapak terminal yang telah dipilih tersebut seperti pada Tabel berikut.

Tabel 5. Skoring Setiap Kriteria Terhadap Lokasi Mikro Tapak Terminal

\begin{tabular}{llll}
\hline \multirow{2}{*}{ No } & \multirow{2}{*}{ Kriteria Penilaian } & \multicolumn{2}{c}{ Skoring Lokasi Tapak } \\
\cline { 3 - 4 } & & 100 & \multicolumn{1}{c}{ Lokasi 1 } \\
\hline 1 & Kondisi luas daratan dan kontur & 80 & 80 \\
\hline 2 & Kestabian tanah dasar & 100 & 80 \\
\hline 3 & Kemudahan dalam pembangunan & 100 & 100 \\
\hline 4 & Kedekatan dengan akses jalan & 90 & 90 \\
\hline 5 & Kesesuaian dengan RTRW & & \\
\hline
\end{tabular}




\begin{tabular}{clll}
\hline \multirow{2}{*}{ No } & \multirow{2}{*}{ Kriteria Penilaian } & \multicolumn{2}{c}{ Skoring Lokasi Tapak } \\
\cline { 3 - 4 } & & Lokasi 1 & Lokasi 2 \\
\hline 6 & Kedekatan dengan jaringan jalan eksisting & 80 & 80 \\
\hline 7 & Pola tata guna lahan di lokasi & 100 & 80 \\
\hline 8 & Kondisi hidrologi & 80 & 80 \\
\hline \multirow{2}{*}{ total } & $\mathbf{6 9 0}$ & $\mathbf{6 7 0}$ \\
\hline
\end{tabular}

\section{1) Distribusi tingkat kepentingan tiap kriteria}

Pada analisis ini, dilakukan sebuah survey kecil dengan bantuan beberapa masyarakat Kabupaten Mamuju Tengah sebagai responden. Secara umum hasil wawancara penentuan prioritas kriteria tersebut dalam diagram distribusi frekwensi prioritas atau tingkat kepentingan dari setiap kriteria yang diajukan.

Dari beberapa responden distribusi untuk prioritas 4 terjadi paling bayak pada kiteria 2 yaitu kedekatan dengan akses jalan, dimana kriteria ini mendapat dukungan dari responden sekitar 66,67\%. Sebanyak 50\% responden menempatkan kriteria kestabilan tanah dasar dan kesesuaian dengan RTRW sebagai prioritas utama, 33,33\% responden menepatkan kemudahan dalam pembangunan, kedekatan dengan jaringan jalan eksisting dan pola tata guna lahan sebagai prioritas utama, dan 16,67\% responden menepatkan kriteria kondisi luas daratan dan kontur dan kondisi hidrologi sebagai prioritas utama. Untuk prioritas kedua dan seterusnya dapat dilihat pada gambar berikut

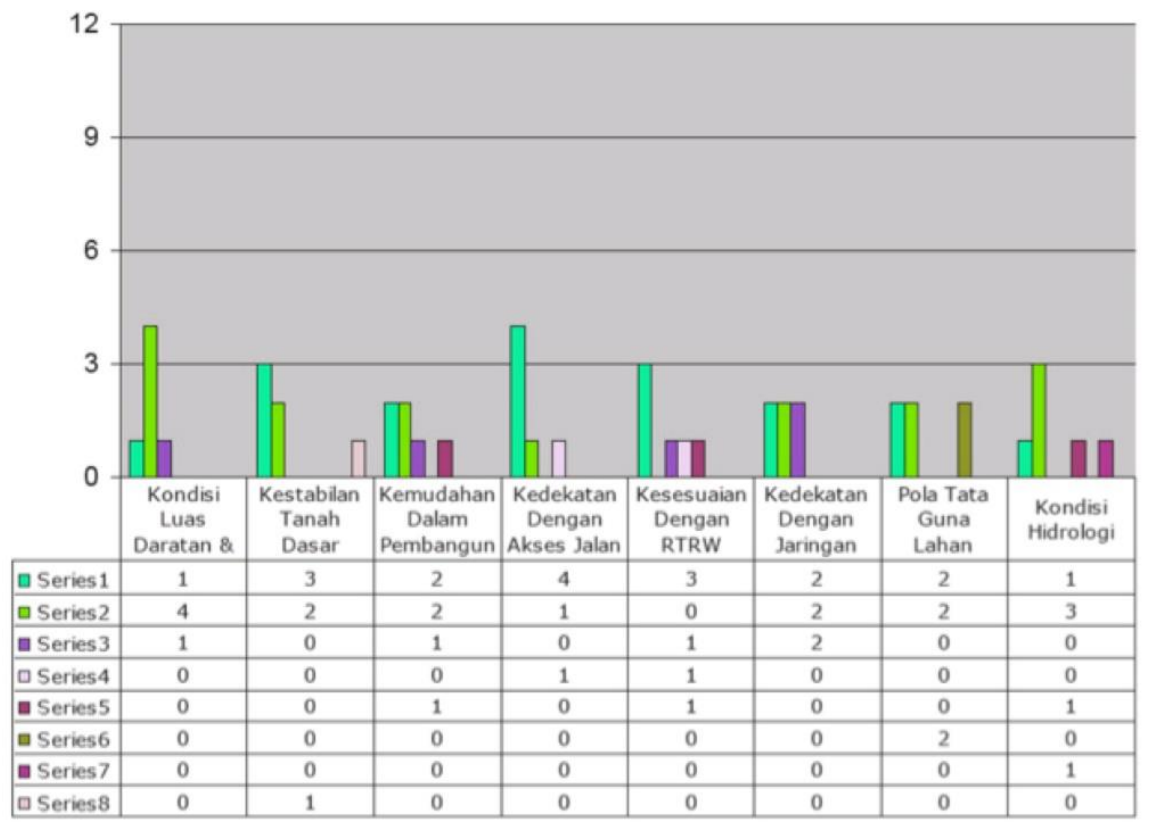

Gambar 4. Distribusi Prioritas Tingkat Kepentingan Antar Kriteria Pemilihan Lokasi

\section{2) Bobot antar kriteria menurut responden}

Pembobotan kriteria dilakukan atas persepsi responden wakil stakeholders yang diwawancarai. Adapun proses pembobotan untuk mendapatkan bobot kepentingan setiap kriteria secara umum dilakukan dengan metodologi sebagai berikut: (a) Membuat matriks perbandingan berpasangan (pairwise comparison matrix) untuk setiap responden untuk mendapatkan bobot kriteria dari setiap responden; dan (b) Membuat Rata-rata bobot untuk seluruh stakeholders dari hasil rata-rata setiap responden yang dibuat pada poin sebelumnya. Proses pembobotan untuk mendapatkan 
bobot kepentingan setiap kriteria secara umum dilakukan dengan metodologi sebagai berikut: (a) Membuat matriks perbandingan berpasangan (pairwise comparison matr $i x)$ untuk setiap responden untuk mendapatkan bobot kriteria dari setiap responden; (b) Membuat rata-rata bobot kriteria setiap stakeholders; dan (c) Membuat Rata-rata bobot untuk seluruh stakeholders dari hasil rata-rata setiap kelompok yang dibuat pada poin sebelumnya.

Beberapa tabel berikut menyajikan contoh hasil matriks perbandingan berpasangan untuk setiap wakil stakeholders. Dalam setiap tabel telah ditampilkan data mengenai bobot kriteria dan eigen value yang menyatakan tingkat konsistensi dari jawaban yang disampaikan.

Tabel 6. Pairwise Comparison Responden

\begin{tabular}{|c|c|c|c|c|c|c|c|c|c|c|c|}
\hline \multicolumn{9}{|c|}{ kriteria } & \multirow{2}{*}{$\begin{array}{l}\text { eigen } \\
\text { vector }\end{array}$} & \multirow{2}{*}{$\begin{array}{c}\text { bobot } \\
\text { kriteria }\end{array}$} & \multirow{2}{*}{$\begin{array}{l}\text { eigen } \\
\text { value }\end{array}$} \\
\hline & 1 & 2 & 3 & 4 & 5 & 6 & 7 & 8 & & & \\
\hline 1 & 1.0 & 1.0 & 1.0 & 0.5 & 0.5 & 1.5 & 0.5 & 1.0 & 0.81 & 0.09 & 8.0 \\
\hline 2 & 1.0 & 1.0 & 1.0 & 0.5 & 0.5 & 1.5 & 0.5 & 1.0 & 0.81 & 0.09 & 8.0 \\
\hline 3 & 1.0 & 1.0 & 1.0 & 0.5 & 0.5 & 1.5 & 0.5 & 1.0 & 0.81 & 0.09 & 8.0 \\
\hline 4 & 2.0 & 2.0 & 2.0 & 1.0 & 1.0 & 3.0 & 1.0 & 2.0 & 1.62 & 0.19 & 8.0 \\
\hline 5 & 2.0 & 2.0 & 2.0 & 1.0 & 1.0 & 3.0 & 1.0 & 2.0 & 1.62 & 0.19 & 8.0 \\
\hline 6 & 0.7 & 0.7 & 0.7 & 0.3 & 0.3 & 1.0 & 0.3 & 0.7 & 0.54 & 0.06 & 8.0 \\
\hline 7 & 2.0 & 2.0 & 2.0 & 1.0 & 1.0 & 3.0 & 1.0 & 2.0 & 1.62 & 0.19 & 8.0 \\
\hline \multirow[t]{4}{*}{8} & 1.0 & 1.0 & 1.0 & 0.5 & 0.5 & 1.5 & 0.5 & 1.0 & 0.81 & 0.09 & 8.0 \\
\hline & & & & & & & & & 8.70 & 1.00 & 8.0 \\
\hline & & & & & & & & & & $\mathrm{CI}=$ & 0.0 \\
\hline & & & & & & & & & & $\mathrm{CR}=$ & 0.0 \\
\hline
\end{tabular}

Untuk setiap responden, dibuat matrix diatas dan hasilnya kemudian direkap sehingga menghasilkan bobot setiap kriteria. Analisis pembobotan hasil survey dari para responden yang berasal dari Kabupaten mamuju Tengah disampaikan pada Gambar berikut ini.

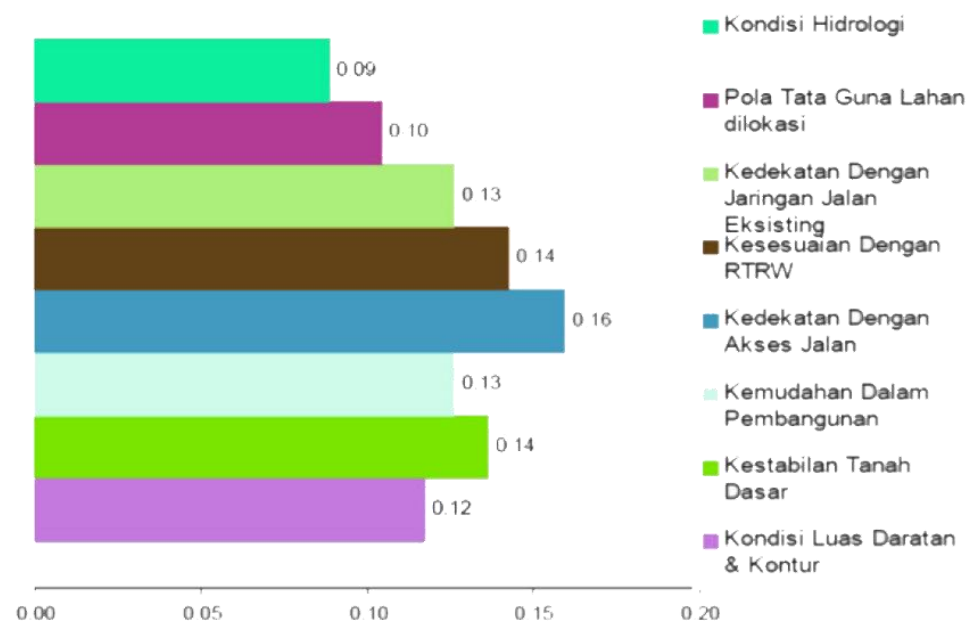

Gambar 5. Distribusi Bobot Kepentingan Tiap Kriteria

Dengan merata-ratakan bobot kriteria untuk setiap responden diperoleh rata-rata bobot 
kriteria seperti yang diperlihatkan pada Gambar 4.10 . secara umum terlihat bahwa bobot tingkat kepentingan antar kriteria relatif fluktuatif, dengan sebaran antara 0,09 sampai dengan 0,16. Hal ini menunjukan bahwa menurut persepsi para pengambil keputusan terkait di Kabupaten Mamuju Tengah semua kriteria yang diusulkan memiliki persaingan tingkat kepentingan yang cukup kuat.

Dari hasil pembobotan tersebut dapat disimpulkan bahwa bobot tingkat kepentingan antar kriteria penentuan lokasi terminal di Kabupaten Mamuju Tengah adalah sebagai berikut:

(a) kriteria terpenting pertama adalah kriteria kedekatan dengan akses jalan dengan bobot kepentingan relatif sebesar 0,16;

(b) kriteria terpenting kedua adalah kriteria kesesuaian dengan RTRW dan kestabilan tanah daar dengan bobot kepentingan relatif sebesar 0,14 ;

(c) kriteria terpenting ketiga adalah kriteria kedekatan dengan jaringan jalan dan kemudahan dalam pembangunan dengan bobot kepentingan relatif sebesar 0,13 ;

(d) kriteria terpenting keempat adalah kriteria kondisi luas daratan dan kontur dengan bobot kepentingan relatif sebesar 0,12 ;

(e) kriteria terpenting kelima adalah kriteria pola tata guna lahan dengan bobot kepentingan relatif sebesar 0,10 ;

(f) kriteria terpenting keenam adalah kriteria kondisi hidrologi dengan bobot kepentingan relatif sebesar 0,09 ;

\section{3) Performance Matrix}

Matriks kinerja (performance matrix) merupakan representasi dari tingkat pemenuhan kriteria dari suatu alternatif yang merupakan hasil perkalian dari skor alternative terhadap variabel kriteria dengan besarnya bobot setiap kriteria. Penyimpulan prioritas untuk setiap alternatif ditentukan oleh besarnya nilai kinerja alternatif (Pi), di mana alternatif yang menunjukkan nilai Pi yang lebih besar akan lebih diprioritaskan. Hasil pembentukan matrik kinerja untuk setiap alternatif lokasi mikro dapat dilihat pada Tabel 7 berikut ini.

Tabel 7. Matrik Kinerja Pemilihan Lokasi Tapak Terminal

\begin{tabular}{|c|c|c|}
\hline \multirow{2}{*}{ Kriteria } & \multicolumn{2}{|c|}{ Skoring lokasi tapak } \\
\hline & lokasi 1 & lokasi 2 \\
\hline kriteria 1 & 11699 & 9359 \\
\hline kriteria 2 & 10886 & 10886 \\
\hline kriteria 3 & 12629 & 10103 \\
\hline kriteria 4 & 15930 & 15930 \\
\hline kriteria 5 & 12825 & 12825 \\
\hline kriteria 6 & 10104 & 10104 \\
\hline kriteria 7 & 6246 & 8328 \\
\hline kriteria 8 & 7078 & 7078 \\
\hline total & 87397 & 84613 \\
\hline
\end{tabular}

Jadi dengan melihat total nilai pada matriks kinerja pada setiap alternatif lokasi tapak mikro dapat dilihat bahwa pada Lokasi 1 (nilai 87.397) ditetapkan sebagai lokasi terbaik dalam pembangunan terminal di Kabupaten Mamuju Tengah dibandingkan dengan lokasi alternatif 2 yang hanya memiliki nilai 84.613. 


\section{KESIMPULAN}

Pada analisis lokasi makro, setelah dilakukan skoring terhadap setiap kriteria dilakukan, dan penilaiaan kualitatif dari sertiap kriteria yang diberikan terhadap kedua alternative lokasi makro terminal yang telah dipilih berdasarkan kriteria tata ruang, transportasi, dampak terhadap aspek sosial dan budaya, dampak terhadap lalu lintas, tenik konstruksi, aspek ekonomi dan finansial, dan dampak terhadap perekonomian daerah, maka diperoleh hasil bahwa lokasi alternatif satu memiliki bobot yang lebih tinggi yaitu 145 dibandingkan dengan loksi alternatif 2 yang hanya 135.

Dari lokasi yang terpilih pada hasil analisis makro lokasi, dipilih kembali dua lokasi alternatif untuk analisis mikro. dengan melihat total nilai pada matriks kinerja pada setiap alternatif lokasi tapak mikro dapat dilihat bahwa pada Lokasi 1 (nilai 87.397) ditetapkan sebagai lokasi terbaik dalam pembangunan terminal di Kabupaten Mamuju Tengah dibandingkan dengan lokasi alternatif 2 yang hanya memiliki nilai 84.613.

\section{DAFTAR PUSTAKA}

Direktorat Jenderal Bina Marga. (1997). Manual Kapasitas Jalan Indonesia (MKJI). Jakarta : Departemen Pekerjaan Umum RI

Fisu AA. (2016). Potensi Demand pengembangan Kanal Jongaya \& panampu Sebagai Moda Transportasi Kota Makassar. Jurnal JMTranslog Trisakti Vol 03 no 03, Jakarta.

Humang Windra Priatna \& Amrin. (2016) Peningkatan Akses Jalan Untuk Menunjang Distribusi Hasil Produksi Kota Terpadu Mandiri (KTM) Air Terang Kab. Buol. Jurnal Pena Teknik Universitas Andi Djemma, Palopo.

Humang Windra Priatna \& Zulfadly. (2016). Analisis Keterpaduan Moda Transportasi Angkutan Penyeberangan Dengan Jalan Raya di Pelabuhan Bajoe Kab. Bone. Jurnal Pena Teknik Universitas Andi Djemma, Palopo.

Keputusan Menteri. (1995). Keputusan Menteri Perhubungan No 31 Tahun 1995 Tentang Terminal Transportasi Jalan. Jakarta : Departemen Perhubungan

Natsir Rakhmawati. (2016). Karakteristik Kinerja Moda Angkutan Umum Kota Palopo (Studi Kasus Penumpang Bus Executive, Suspensi Udara, Scania - PO Bintang Prima. Jurnal Pena Teknik Universitas Andi Djemma, Palopo.

Rita Ahmad Rusli. (2014). Usulan Penentuan Lokasi dan Tapak Terminal Regional di Kota Bintuni. Jurnal Planesa Vol.05 Universitas Esa Unggul, Jakarta. 
PENA TEKNIK: Jurnal Ilmiah Ilmu-Ilmu Teknik

Volume 3, Nomor 1, Maret 2018 : 1 - 12

Halaman ini sengaja dikosongkan 